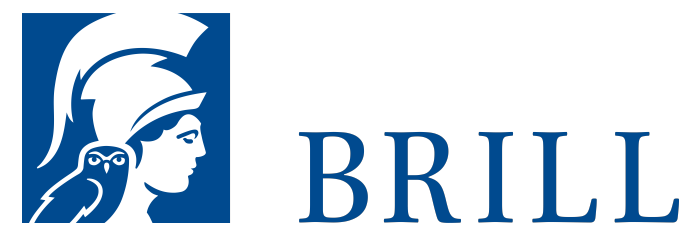

\title{
Der philosophische Begriff des Gebrauchs
}

\author{
Platon, Kant, Wittgenstein \\ Author: Mathias Schlicht von Rabenau
}

Der Begriff des Gebrauchs fand in der Philosophiegeschichte vielfach Verwendung. Dieses Buch untersucht seine Bedeutung und Entwicklung und knüpft dabei an Diskussionen um pragmatische und performative Ansätze der gegenwärtigen Philosophie an. Exemplarisch werden die Philosophien Platons, Kants und Wittgensteins in den Blick genommen. Platon fragte nicht nur nach der Wahrheit des Wissens, sondern auch nach Formen des Wissens, von denen unterschiedlicher Gebrauch (???s??) gemacht werde. Nach Kant hat in der 'allgemeinen Menschenvernunft [... ] ein jeder seine Stimme', die, wie jede Stimme, unverwechselbar individuell ist. So kann man von der Vernunft, was immer sie sei, nur individuellen Gebrauch machen. Wittgenstein wiederum fand die Bedeutung eines Wortes in dessen Gebrauch. Die Untersuchung zeigt schließlich, dass dem Begriff des Gebrauchs in denkbar unterschiedlichen philosophiehistorischen Kontexten eine vergleichbare systematische Funktion zukommt, womit ihm ein philosophischer Sinn im Ganzen zugemessen werden kann: Er bringt die pragmatischen Bedingungen, die philosophische Theorien zunächst ausblenden, um sich überhaupt als Theorien konstituieren zu können, wieder ins Spiel.

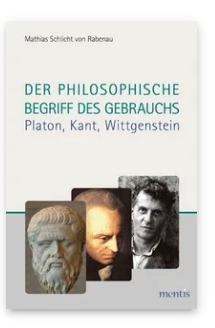

Pages: 320

Seiten

Language:

German

Subjects:

General,

Philosophy

Publisher: Brill | mentis

E-Book (PDF)

Released online:

o1 Oct 2014

ISBN: 978-3-

95743-986-4

List price

Paperback

Publication date:

o1 Oct 2014

ISBN: 978-3-

89785-071-2

List price 
For more information see brill.com

Order information: Order online at brill.com +44330 333 0049 | customerservices@brill.com Submission information: brill.com/authors

Titles published by Brill | Fink, Brill | mentis or Brill | Schöningh: +49(o)715413279216| brill@brocom.de 